\title{
HUBUNGAN STATUS GIZI DENGAN PROSES PENYEMBUHAN \\ LUKA DI RSUD H. ANDI SULTHAN DAENG RADJA \\ KABUPATEN BULUKUMBA
}

\author{
${ }^{1}$ Fitriani Yusuf \\ ${ }^{2}$ Tenriwati
}

\footnotetext{
${ }^{I}$ Departemen Keperawatan Anak dan Maternitas Stikes Panrita Husada Bulukumba

${ }^{2}$ Departemen Keperawatan Anak dan Maternitas Stikes Panrita Husada Bulukumba
}

\section{Alamat Korespondensi:}

Ns.Fitriani,S.Kep,M.Kes

Program Studi S1 Ilmu Keperawatan

Sekolah Tinggi Ilmu Kesehatan Panrita Husada

Bulukumba, 04132514721

HP: 085255001632

Email: fitrianiviviambo@gmail.co.id 


\begin{abstract}
ABSTRAK
Saat ini, angka kejadian luka di Indonesia cukup tinggi, terlihat dari data kejadian kecelakaan lalu lintas masyarakat umum. Ada beberapa faktor yang mempengaruhi penyembuhan luka, salah satunya yaitu status gizi. Berdasarkan pengambilan data awal yang dilakukan oleh peneliti diruang seruni bedah pada 1 bulan terakhir yaitu pada bulan maret, di dapatkan bahwa jumlah pasien luka yaitu sebanyak 109 pasien, dimana jumlah lakilaki sebanyak $78(71,56 \%)$ sedangkan jumlah perempuan sebanyak 31 (28,44\%).Tujuan penelitian ini adalah Untuk mengetahui hubungan antara status gizi dengan proses kesembuhan luka di RSUD. H.Andi. Sulthan Daeng Radja Kab.Bulukumba. Penelitian ini menggunakan desain jenis penelitian ini merupakan penelitian kuantitatif. Jenis penelitian ini menggunakan penelitian observasional analitik dengan pendekatan cross sectional. Sampel penelitian ini sebanyak 41 responden yang diambil dengan metode purposive sampling.Analisis data dalam penelitian ini menggunakan uji statistik uji chi-square (chi kuadrat). Hasil analisis menggunakan uji statistik chi-square dengan tingkat kepercayaan $(\alpha=0,05)$. Berdasarkan hasil uji ini, didapatkan nilai $p$ adalah 0,001, dengan demikian $p<\alpha(0,001<0,05)$, maka Ho ditolak dan Ha diterima. Kesimpulan dari penelitian ini adalah terdapat hubungan antara status gizi dengan proses kesembuhan luka di RSUD. H.Andi. Sulthan Daeng Radja Kab.Bulukumba. Peneliti menyarankan Agar penelitian ini dijadikan sebagai bahan pertimbangan dalam pemenuhan gizi pada pasien perawatan luka di RSUD.H.A. Sulthan Daeng Radja Kab.Bulukumba serta penelitian ini dapat dilanjutkan dengan melakukan penelitian terkait dengan proses penyembuhan luka dan mengaitkannya dengan variabel yang lain..
\end{abstract}

Kata Kunci: Penyembuhan Luka, Status Gizi

\begin{abstract}
At present, the incidence of injuries in Indonesia is quite high, as seen from data on traffic accidents in the general public. There are several factors that affect wound healing, one of which is nutritional status. Based on the preliminary data retrieval conducted by researchers in the seruni surgery room in the last 1 month namely in March, it was found that the number of wounded patients was 109 patients, where the number of men was 78 (71.56\%) while the number of women was 31 (28.44\%) The purpose of this study was to determine the relationship between nutritional status and the wound healing process in RSUD. H. Andi. Sulthan Daeng Radja Kab. Bulukumba. This research uses the type of design of this research is quantitative research. This type of research uses analytic observational research with cross sectional approach. The sample of this study were 41 respondents taken by purposive sampling method. Data analysis in this study used the chi-square test (chi square test). The results of the analysis used the chi-square statistical test with a confidence level $(\alpha=0.05)$. Based on the results of this test, the $p$ value is 0.001, thus $p<\alpha(0.001<0.05)$, then Ho is rejected and Ha is accepted. The conclusion of this study is that there is a relationship between nutritional status and the process of wound healing in RSUD. H. Andi. Sulthan Daeng Radja Kab. Bulukumba. Researchers suggest that this study be used as a material consideration in the fulfillment of nutrition in wound care patients in RSUD.H.A. Sulthan Daeng Radja Kab. Bulukumba and this research can be continued by conducting research related to the wound healing process and linking it with other variables.
\end{abstract}

Keywords: Wound Healing, Nutritional Status 


\section{PENDAHULUAN}

Kulit adalah suatu organ pembungkus seluruh permukaan luar tubuh, Kulit merupakan organ terberat dan terbesar dari tubuh.Kulit mempunyai beberapa fungsi utama yang penting untuk tubuh, yaitu sebagai pelindung dari bakteri dan mikroba lainya, dari trauma mekanik, kimiawi, suhu ekstrim panas, dingin, kelembapan, kekeringan serta radiasi ultraviolet (Sussman $\&$ Bates-Jensen, 2012). Adanya suatu trauma baik itu secara mekanik, kimia, radiasi dan lainnya akan menyebabkan struktur kulit rusak dan menimbulkan suatu keadaan yang disebut sebagai luka (Kusuma, 2009).

Pada tahun 2009, sebuah asosiasi luka di Amerika melakukan penelitian tentang insiden luka didunia berdasarkan etiologi penyakit. Diperoleh data untuk luka bedah ada 110,30 juta kasus, luka trauma 1,60 juta kasus, luka lecet ada 20,40 juta kasus, luka bakar 10 juta kasus, ulkus dekubitus 8,50 juta kasus, ulkus vena 12,50 juta kasus, ulkus diabetic 13,50 juta kasus, amputasi 0,20 juta pertahun, karsinoma 0,60 juta kasus pertahun, melanoma 0,10 juta, komplikasi kanker kulit ada sebanyak 0,10 juta kasus ( Diligence, 2009).

Ketika luka timbul, beberapa efek akan muncul diantaranya hilangnya seluruh atau sebagian fungsi organ, respon stres simpatis, perdarahan dan pembekuan darah, kontaminasi bakteri dan kematian sel. Luka yang tidak sembuh dalam waktu yang lama dengan berbagai etiologi dikhawatirkan mengalami komplikasi.Komplikasi luka dapat menimbulkan berbagai dampak negatif.

Penyembuhan luka terdiri atas tiga fase, yaitu fase inflamasi, fase proliferasi, dan fase maturasi atau remodeling. Antara fase yang satu dan fase lainnya memiliki rentang waktu yang saling bersinggungan atau tumpah tindih.proses perbaikan sel(penyembuhan luka) bergantung pada kedalaman luka dikulit. Proses ini terjadi secara sederhana yang diawali dengan pembersihan(debris) area luka, pertumbuhan jaringan baru hingga permukaan datar, dan pada akhirnya luka menutup(Arisanty, 2013).

Nutrisi secara spesifik diperlukan untuk meningkatkan kekuatan luka, menurunkan dehisensi luka, menurunkan kerentanan terhadap infeksi dan sedikit menimbulkan parut. Simpanan nutrient dan nutrisi yang baik juga akan mempercepat penyembuhan dan/atau menurunkan angka infeksi. Namun, nutrisi di sini harus mematuhi rekomendasi diet seimbang dan bergizi tinggi. Bahan makanan yang terdiri dari empat golongan utama, yaitu protein, lemak, karbohidrat, dan mikronutrien (vitamin dan mineral) penting untuk proses biokimia normal, yang juga dapat membantu tubuh dalam meningkatkan mekanisme pertahanan tubuh (sistem imun), dan pada 
akhirnya akan membantu proses penyembuhan luka (Hanifah, 2009 dikutip dalam Widjianingsih, 2013).

Berdasarkan pengambilan data awal yang dilakukan oleh peneliti di RSUD H.A.Sulthan DG. Radja Kab. Bulukumba, jumlah pasien luka pada tahun 2012 sebanyak 377 pasien dari jumlah pasien rawat sebanyak 1823 pasien, pada tahun 2013 sebanyak 391 dari jumlah 2603 pasien serta pada tahun 2014 sebanyak 514 dari jumlah 2792 pasien.Adapun rata-rata lama penyembuhan luka yang tidak mengalami infeksi di RSUD H.A.Sulthan Daeng Radja Kab.Bulukumba yaitu 4 sampai 7 hari.

\section{METODE}

Penelitian ini dilakukan di RSUD. H.A. Sulthan Daeng Radja Kab.Bulukumba di ruangan seruni dan perawatan bedah. Waktu penelitian pada bulan juni sampai juli 2016

Populasi dalam penelitian ini adalah pasien yang akan melakukan perawatan luka dengan jumlah 263 orang. sampel dalam penelitian ini yakni sebanyak 52 orang. tekhnik pengambilan sampel dalam penelitian ini, dilakukan berdasarkan purposive sampling. Tekhnik penentuan sampel ini bertujuan dilakukan tidak berdasarkan strata, kelompok, atau acak, atau berdasarkan pertimbangan atau tujuaan tertentu.
Instrumen untuk menilai status gizi dilakukan dengan metode antropometri yaitu dengan menilai indeks massa tubuh. Sedangkan untuk mengukur tentang proses kesembuhan luka dilakukan dengan metode observasi dan di lihat pada hari ke 3 sejak luka berlangsung apakah keadaan luka sudah memasuki fase proliferasi ataukah masih pada fase inflamasi berdasarkan tanda dari luka tersebut dengan menggunakan observasi atau pengamatan dengan alat ukur observasi berupa lembar check list yang berisi tentang gejala dari sasaran pengamatan dengan kriteria apabila terjadi proses proliferasi saat terjadi pertumbuhan sel-sel baru, terjadi pengecilan luas luka, serta nampak warna merah muda pada luka yang menutupi luka dan tidak terjadi proses proliferasi saat masih terjadi proses inflamasi yang ditandai dengan bengkak, kemerahan, hangat/demam, ketidaknyamanan/nyeri dan penurunan fungsi tubuh.

Metode observasi yang berpedoman pada lembar check list untuk mengukur tentang perawatan luka dan hubungannya dengan terjadinya infeksi di ruang seruni dan perawatan bedah RSUD H.A.Sulthan Daeng Radja Kab.Bulukumba .

\section{HASIL}

Berdasarkan tabel 1 dapat diketahui bahwa responden yang terbanyak pada penelitian ini adalah berjenis kelamin laki- 
laki, dengan jumlah yaitu 25 orang atau dengan persentase sebesar $61,0 \%$.

Berdasarkan tabel 2 dapat diketahui bahwa responden dengan umur terbanyak pada penelitian ini adalah kategori dewasa awal yaitu sebanyak 27 orang atau dengan persentase $65,9 \%$.

Berdasarkan tabel 3 dapat diketahui bahwa status gizi terbanyak pada responden yaitu berada pada kategori tidak normal dengan frekuensi sebanyak 21 ( $51.2 \%)$.

Berdasarkan tabel 4, terlihat bahwa status gizi responden kategori normal dengan terjadinya penyembuhan luka sebanyak 19 responden $(95,0 \%)$, kategori status gizi normal dengan tidak terjadinya penyembuhan luka sebanyak 1 responden $(5,0 \%)$, kategori tidak normal dengan terjadi penyembuhan luka sebanyak 6 responden $(28,60 \%)$, kategori tidak normal dengan tidak terjadi penyembuhan luka sebanyak 15 responden $(71,40 \%)$.

Berdasarkan hasil analisis menggunakan uji statistik chi square diperoleh nilai $\rho=0,001<\alpha=0,05$. Berdasarkan hasil akhir tersebut dapat disimpulkan yaitu terdapat hubungan status gizi dengan proses penyembuhan luka di RSUD. H. A. Sulthan Daeng Radja Kab. Bulukumba

\section{PEMBAHASAN}

Berdasarkan penelitian yang dilakukan sebagian besar status gizi responden memiliki status gizi yang berada pada kategori tidak normal yaitu 21 responden $(51,2 \%)$ sedangkan sebagian responden berada pada kategori status gizi normal sebanyak $20(48,8 \%)$.

Hal ini sesuai dengan penelitian Said (2013 ) yang mengatakan bahwa malnutrisi merupakan suatu masalah yang umum terjadi pada pasien dirumah sakit, termasuk pasien luka. Prevalensi malnutrisi pada pasien rawat inap di rumah sakit telah teridentifikasi dalam banyak studi.Pada sebuah rumah sakit di Inggris ditemukan malnutrisi sebesar 40\%. Studi-studi yang lainmenunjukkan prevalensi malnutrisi di rumah sakit berkisar 40\% sampai 59\%.

Menurut asumsi peneliti, banyaknya responden yang berada pada kategori gizi tidak normal disebabkan karena sebagian besar responden tidak memiliki nafsu makan yang adekuat selama dirawat dirumah sakit. Selain itu, menu yang disiapkan dirumah sakit tidak beragam serta lingkungan dari rumah sakit yang menurunkan nafsu makan dari responden. Selain itu, lingkungan rumah sakit yang tidak mendukung dalam meningkatkan nafsu makan dari responden serta stress akibat berbagai keluhan terkait masalah kesehatan yang dialaminya

Berdasarkan penelitian yang dilakukan sebagian besar luka dari responden berada pada kategori terjadi proses penyembuhan yaitu sebanyak 26 responden (63.4\%) 
sedangkan sebagian kecil responden berada pada kategori tidak terjadi penyembuhan luka sebanyak 15 (36,6\%). Dengan memberikan penilaian berdasarkan kriteria terjadi pertumbuhan sel-sel baru, terjadi pengecilan luka, dan nampak merah mudah pada daerah yang menutupi luka.

Hal ini sesuai dengan penelitian Puspitasari ( 2011) yang mengatakan bahwa Personal hygiene juga mempengaruhi proses penyembuhan luka karena kuman setiap saat dapat masuk melalui luka bila kebersihan diri kurang (Gitarja dan Hardian, 2008). Ketika perawat kurang memperhatikan Standar Operasional Prosedur (SOP) atau prosedur tetap perawatan luka. Sebagai contoh, dalam melakukan perawatan luka alat-alat yang digunakan untuk merawat luka hanya satu set perawatan luka dan digunakan untuk semua pasien yang membutuhkan perawatan luka pada hari tersebut. Selain itu perawat juga kurang memperhatikan teknik aseptik, misalnya sesudah melakukan perawatan luka pada satu pasien, perawat tidak segera mencuci tangan kembali dan mengganti dengan handscoon yang baru dan steril tetapi langsung melakukan perawatan luka pada pasien yang lain. Padahal seharusnya sebelum dan sesudah melakukan perawatan luka pada satu orang pasien, harus selalu mencuci tangan dan mengganti handscoon dengan yang steril.Hal tersebut di atas tidak sesuai dengan SOP perawatan luka. Padahal kita sebagai seorang perawat seharusnya tahu bahwa SOP merupakan tata cara atau tahapan yang dibakukan dan harus dilalui untuk menyelesaikan suatu proses kerja tertentu termasuk didalamnya tindakan perawatan luka. Apabila SOP tersebut tidak dilakukan dengan benar, ditakutkan akan berpengaruh terhadap proses penyembuhan luka tersebut.

Menurut asumsi peneliti, banyaknya responden yang mengalami proses penyembuhan luka, disebabkan karena perbedaan frekuensi status gizi normal dengan tidak normal hanyalah 1 responden, dimana rata-rata kategori status gizi normal mengalami penyembuhan luka serta sebagian besar dari responden berada pada status gizi tidak normal juga mengalami kesembuhan luka. Hal tersebut didasarkan karena, cadangan lemak pada orang yang mengalami status gizi kurang masih digunakan untuk memperbaiki jaringan yang rusak sehingga penyembuhan luka masih tetap terjadi.

Berdasarkan hasil analisis menggunakan uji statistik chi square diperoleh nilai $\rho=0,001<\alpha=$ 0,05.Berdasarkan hasil akhir tersebut dapat disimpulkan bahwa terdapat hubungan status gizi dengan proses penyembuhan luka di RSUD.H.A.Sulthan Daeng.Radja Kab. Bulukumba.

Hasil penelitian diatas sejalan dengan penelitian Widjianingsih (2013) yang menyatakan bahwa Hal ini dikarenakan ada 
beberapa zat gizi yang memang sangat diperlukan untuk mendukung sistem imun tubuh serta berperan penting dalam proses penyembuhan luka. Nutrisi secara spesifik diperlukan untuk meningkatkan kekuatan luka, menurunkan dehisensi luka, menurunkan kerentanan terhadap infeksi dan sedikit menimbulkan parut. Simpanan nutrient dan nutrisi yang baik juga akan mempercepat penyembuhan dan/atau menurunkan angka infeksi. Nutrisi yang baik sangat penting untuk mencapai keberhasilan penyembuhan luka.Namun, nutrisi di sini harus mematuhi rekomendasi diet seimbang dan bergizi tinggi. Bahan makanan yang terdiri dari empat golongan utama, yaitu protein, lemak, karbohidrat, dan mikronutrien (vitamin dan mineral) penting untuk proses biokimia normal, yang juga dapat membantu tubuh dalam meningkatkan mekanisme pertahanan tubuh (sistem imun), dan pada akhirnya akan membantu proses penyembuhan luka (Hanifah, 2009).

\section{KESIMPULAN DAN SARAN}

Sebagian besar status gizi pada responden berada pada kategori status gizi kurang dengan frekuensi $21 \quad(51,2 \%)$ sedangkan yang berada pada kategori status gizi baik sebanyak 20 (49,8\%). Sebagian besar proses penyembuhan luka pada responden berada pada kategori terjadi proses penyembuhan luka dengan frekuensi sebanyak $26(63.4 \%)$ sedangkan yang tidak terjadi penyembuhan luka sebanyak 15 $(36.6 \%)$.

Terdapat hubungan status gizi dengan proses penyembuhan luka di RSUD.H.A.Sulthan Daeng Radja Kab.Bulukumba tahun 2015 denganmenggunakan uji statistik chi square diperoleh nilai $\rho=0,001<\alpha=0,1 \quad 51 \quad \mathrm{r}$ penelitian ini dijadikan sebagai vallan pertimbangan dalam pemenuhan gizi pada pasien perawatan luka di RSUD.H.A. Sulthan Daeng Radja Kab.Bulukumba. Agar penelitian ini dapat dijadikan referensi bagi tenaga kesehatan untuk lebih memperhatikan status gizi dari pasien. Agar penelitian ini dapat menjadi bahan referensi untuk penelitian selanjutnya untuk melakukan penelitian terkait dengan proses penyembuhan luka dan mengaitkannya dengan variabel yang lain.

\section{DAFTAR PUSTAKA}

Arisanty, Irma P. (2013). Konsep dasar manajemen perawatan luka. EGC: Jakarta.

Alimul, A.Aziz. (2009). Pengantar kebutuhan dasar manusia aplikasi konsep dan proses keperawatan. Salemba Medika: Jakarta.

Devi,(2013). “ Hubungan Motivasi Dengan Kepatuhan Perawat Pelaksana Dalam Melaksanakan Perawatan Luka post Operasi Sesuai dengan 
Sop Di RSUD Batang” Jurnal : hal 3.

Fatimah, (2011). “faktor-faktor yang berhubungan dengan terjadinya infeksi nasokomial luka operasi di ruang bedah RSUD Fatmawati tahun 2011" Jurnal.

Hidayat, Alimul, A.Aziz. (2011). Metode penelitian kebidanan dan tekhnik analisis data. Salemba medika : Jakarta.

Himatusujanah, (2010). "hubungan tingkat kepatuhan perawatan luka dengan kejadian infeksi luka post sectio secaria di ruang mawar I RSUD DR. Moewardi Surakarta” Jurnal.

Jacop, Annamma,et.al., (2014). Buku ajar Clinical nursing procedures. Binarupa aksara publisher: Tangeran selatan.

Kowalak, et. Al., (2009). Buku ajar patofisiologi. EGC: Jakarta.

Puspitasari, Herlina ( 2011 ) . "Faktor Faktor Yang Mempengaruhi Penyembuhan Luka Post Operasi Sectio Caesarea (Sc)”. Jurnal.

Resfi, (2012). "Faktor-Faktor Yang Mempengaruhi Perilaku perawat Terhadap Upaya Pencegahan Infeksi Luka Post Operasi Pada Pasien Bedah Ekstremitas Bawah”: jurnal. Hal 1 dan 2.

Saryono., Anggraeni, Mekar Dewi. (2013). Metodologi penelitian kualitatif dan kuantitatif dalam bidang kesehatan. Nuha Medika: Yokyakarta.

Setyarini, (2013). "Perbedaan Alat Ganti Verband Antara Dressing Set Dan Dressing Trolley Terhada P Resiko Infeksi Nosokomial Dalam Perawatan Luka Post Operasi”: jurnal. Hal 1 dan 2.

Sugiono. (2014). Statistika untuk penelitian, Alfabeta : Bandung.

Sutrisno, (2014). "hubungan pengetahuan perawat terhadap perilaku pencegahan infeksi luka operasi di RSUD Barru” Jurnal.

Suryati,Yayat. ( 2013 ). “Hubungan Tingkat Pengetahuan Ibu Nifas Tentang Perawatan Luka Perineum Dan Status Gizi Dengan Proses Penyembuhan Luka”. Jurnal.

Stikes Panrita Husada. (2015). “Buku Panduan Penyusunan Skripsi”. Ooasa : Bulukumba.

Widjianingsih, Elok. ( 2013 ). "Hubungan Tingkat Konsumsi Gizi Dengan Proses Penyembuhan Luka Pascaoperasi Sectio Cesarea”.jurnal. 
Tabel 1. Distribusi Jumlah Responden Berdasarkan Jenis Kelamin Di RSUD H.A.Sulthan DG.Radja Kab.Bulukumba tahun 2015

\begin{tabular}{clc}
\hline Jenis Kelamin & Frekuensi (f) & Persentase (\%) \\
\hline Laki-Laki & 25 & 61.0 \\
Perempuan & 16 & 39,0 \\
\hline Total & $\mathbf{4 1}$ & $\mathbf{1 0 0}$ \\
\hline
\end{tabular}

Tabel 2. Distribusi Jumlah Responden Berdasarkan Usia Di RSUD H.A.Sulthan DG.Radja Kab.Bulukumba tahun 2015

\begin{tabular}{clc}
\hline Usia & Frekuensi (f) & Persentase (\%) \\
\hline Remaja & 14 & 34.1 \\
Dewasa Muda & $\mathbf{2 7}$ & $\mathbf{6 5 . 9}$ \\
\hline Total & $\mathbf{4 1}$ & $\mathbf{1 0 0}$ \\
\hline
\end{tabular}

Tabel 3.Distribusi Jumlah Responden Berdasarkan Status Gizi Di RSUD. H.A.Sulthan DG.Radja Kab.Bulukumba Tahun 2015

\begin{tabular}{clc}
\hline Status gizi & Frekuensi (f) & Persentase (\%) \\
\hline Normal & 20 & 48.8 \\
Tidak normal & 21 & 51.2 \\
\hline Total & 41 & 100 \\
\hline
\end{tabular}

Tabel 4.Analisis Hubungan Status Gizi Dengan Proses Penyembuhan Luka Di RSUD.H.A.Sulthan Daeng.Radja Kab. Bulukumba.

\begin{tabular}{|c|c|c|c|c|c|c|c|}
\hline \multirow{3}{*}{ Status Gizi } & \multicolumn{6}{|c|}{ Penyembuhan luka } & \multirow{3}{*}{$\rho$} \\
\hline & \multicolumn{2}{|c|}{ Terjadi penyembuhan } & \multicolumn{2}{|c|}{$\begin{array}{l}\text { Tidak Terjadi } \\
\text { penyembuhan }\end{array}$} & \multicolumn{2}{|c|}{ Total } & \\
\hline & $\mathbf{n}$ & $\%$ & $\mathbf{n}$ & $\%$ & $\mathbf{N}$ & $\%$ & \\
\hline Normal & 19 & 95.0 & 1 & 5.0 & 20 & 100 & \\
\hline $\begin{array}{l}\text { Tidak } \\
\text { normal }\end{array}$ & 6 & 28.60 & 15 & 71.40 & 21 & 100 & 0.001 \\
\hline Total & 25 & 60.97 & 16 & 39.03 & 41 & 100 & \\
\hline
\end{tabular}

